Theoretical/Conceptual Article

\title{
KONSELING RASIONAL EMOTIF PERILAKU: SEBUAH TINJAUAN FILOSOFIS
}

\author{
Bakhrudin All Habsy * \\ Universitas Darul Ulum, \\ Jombang
}

\begin{abstract}
RATIONAL EMOTIVE BEHAVIOR COUNSELING: A PHILOSOPHICAL REVIEW. Rational Emotive Behavior Counseling is a comprehensive, active-directive, philosophical and empirical counseling based on psychotherapy that focuses on solving problems of emotional and behavioral disorders, as well as delivering individuals to happier and fulfilling lives more lives. The foundation of the philosophy of Rational Emotive Behavior Counseling is phenomology, which implies that there is no problem within oneself, which causes one to be troubled is his or her own. Rational emotive behavior counseling is done by using a varied and systematic procedure that is specifically intended to alter behavior within the boundaries of objectives that counselors and counselees work on together. General Purpose Rational Emotive Behavior Counseling helps counselees to identify irrational belief systems and then modify them to become more rational. Rational Counseling Emotive Behavior is practiced around the world and has many counseling applications, over 50 years of existence, Rational Emotive Behavior Counseling has been successfully applied to individuals, groups, marriages, families and for a variety of issues.
\end{abstract}

KEYWORDS: REBT, Philosophical Review.

* Corresponding Author: Program Studi Bimbingan dan Konseling, FKIP Universitas Darul Ulum Jombang; Jl. Gus Dur No.29A, Mojongapit, Kec. Jombang, Kabupaten Jombang, Jawa Timur 61419, Indonesia; Email: bakhrudin.bk@undar.ac.id

Article History: Received: 02-11-2017; Revised: 14-12-2017; Accepted: 03-1-2018

Permalink: http://ijec.ejournal.id/index.php/counseling/article/view/25

How to cite (APA): Habsyi, B. A. (2018). Konseling rasional emotif perilaku: Sebuah tinjauan filosofis. Indonesian Journal of Educational Counseling, 2(1), 13-30.

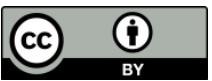

This is an open access article distributed under the terms of the Creative Commons Attribution 4.0 International License, which permits unrestricted use, distribution, and reproduction in any medium, provided the original work is properly cited. @ 2018, Bakhrudin All Habsy.

\section{PENDAHULUAN}

Konseling Rasional Emotif Perilaku merupakan pengembangan dari rational therapy dan rational emotive therapy yang diciptakan dan dikembangkan oleh Albert Ellis sejak menekuni bidang psikologi klinis pada tahun 1942. Albert Ellis seorang psikoterapis yang terinspirasi oleh ajaran-ajaran filsuf Asia, dan Barat klasik dan modern yang lebih mengarah pada teori belajar kognitif. 
Asal-usul Konseling Rasional Emotif Perilaku dapat ditelusuri dengan filosofi dari Stoisisme di Yunani kuno yang membedakan tindakan dari interpretasinya. Epictetus dan Marcus Aurelius dalam bukunya "The Enchiridion", menyatakan bahwa manusia tidak begitu banyak dipengaruhi oleh apa yang terjadi pada dirinya, melainkan bagaimana manusia memandang/menafsirkan apa yang terjadi pada dirinya (People are not disturbed by things, but by the view they take of them). Ellis di antara para ahli kognitif yang lain tergolong yang paling populer, seperti halnya Beck, Ellis memiliki asumsi bahwa manusia memainkan peran penting dalam menyebabkan kesulitan sendiri melalui cara mereka dalam menginterpretasi situasi atau peristiwa lingkungan, dengan kata lain kognisi manusia merupakan sumber kesulitannya.

Menurut Ellis \& Grieger (1986) Konseling Rasional Emotif Perilaku dikembangkan dan dibangun berdasarkan tiga pandangan, yaitu: 1) Filsuf Epictus, yang menyatakan bahwa "orang menjadi terganggu bukan oleh bendabenda, melainkan oleh apa yang dipandangnya tantang benda itu", 2) Adler, yang berpendapat bahwa reaksi serta gaya hidup individu ada hubungannya dengan keyakinan dasarnya sendiri dan karenanya diciptakan secara kognitif, 3) pandangan Shakespeare, yang menyatakan bahwa "tidak ada satupun yang baik dan buruk, kecuali pikiran yang menjadikan demikian".

Ellis mengembangkan teori $\mathrm{A}-\mathrm{B}-\mathrm{C}$, dan kemudian dimodifikasi menjadi pendekatan A-B-C-D-E-F yang digunakan untuk memahami kepribadian dan untuk mengubah kepribadian secara efektif. Melalui Konseling Rasional Emotif Perilaku Ellis mengakui bahwa kognisi, emosi dan perilaku saling berinteraksi dan saling mempengaruhi (Bond \& Dryden, 1996). Jika Rasional Emotif hanya menekankan pada aspek kognitif dan emosi, maka melalui Konseling Rasional Emotif Perilaku Ellis mulai memberikan perhatian pada aspek behavior dalam proses perlakuannya.

Konseling Rasional Emotif Perilaku merupakan salah satu bagian dari cognitive behavior therapy (CBT) (Habsy, 2017). Konseling Rasional Emotif Perilaku menekankan pada peran penting kognisi dalam mempengaruhi fungsi manusia. Mengubah kognisi seseorang adalah cara yang efektif dalam meningkatkan aspek kognitif, emosi dan perilaku. Dalam konseling REBT, Ellis mengakui kognisi, emosi dan perilaku saling berinteraksi satu sama lain (Dryden, 2003). Seperti yang dikemukakan oleh Ellis "Ketika mereka beremosi, mereka juga berpikir dan bertindak. Ketika mereka bertindak, mereka juga berpikir dan beremosi. Ketika mereka berpikir, mereka juga beremosi dan bertindak" (Corey, 2005). 


\section{KAJIAN LITERATUR}

Tujuan penulisan artikel ini adalah (1) Konseling Rasional Emotif Perilaku diharapkan dapat menjadi intervensi yang inovatif, baik secara konseptual dan teknikal dalam pelaksanaan layanan bimbingan dan konseling, (2) Konseling Rasional Emotif Perilaku diharapkan dapat berguna untuk memperkuat dasar pijakan bagi dilaksanakannya penelitian selanjutnya, (3) Konseling Rasional Emotif Perilaku dapat diterapkan oleh para pengguna layanan konseling sebagai pendekatan yang komprehensif. Maka dalam kajian literatur ini penting untuk memaparkan sejarah perkembangan dan rumusan hakikat manusia berdasarkan pandangan Konseling Rasional Emotif Perilaku sebagai arah untuk mengkaji secara filosofis pandangan tersebut.

\section{Sejarah Perkembangan}

Konseling Rasional Emotif Perilaku dikembangkan oleh Albert Ellis, seorang eksistensialis pada tahun 1955. Ellis, psikolog klinis Amerika yang sangat puas dengan psikoanalisis yang telah dilatihkannya pada akhir 1940-an. Konseling Rasional Emotif Perilaku merupakan pengembangan dari rational therapy dan rational emotive therapy, diciptakan dan dikembangkan oleh Albert Ellis sejak ia menekuni bidang psikologi klinis pada tahun 1942. Ellis dilahirkan di Pittsburgh, Pennsylvania pada tahun 1913. Dalam otobiografinya, Ellis mengatakan dia malu terhadap perempuan, pada umur 19 tahun telah memperlihatkan dirinya sebagai seorang terapis kognitif behavior, dia memaksa dirinya untuk berbicara dengan 100 orang perempuan di Bronx, Botanical Garden selama lebih dari satu bulan, dia selalu berusaha untuk menahan kekecewaan pada saat ditolak bebicara oleh perempuan (Habsy, 2014).

Pada tahun 1947, Ellis menggunakan psikoanalisis dan person-centered therapy dalam proses terapi, namun dia merasa kurang puas dengan pendekatan dan hipotesis tingkah laku konseli yang dipengaruhi oleh sikap dan persepsi mereka. Hal inilah yang memotivasinya mengembangkan pendekatan rational emotive dalam psikoterapi yang ia percaya dapat lebih efektif dan efisien dalam memberikan efek terapeutik. Ellis mengembangkan pendekatan ini dikombinasikan dengan model latihan bicara dan tugas pekerjaan rumah yang mencakup bicara di depan umum (Gross \& Capuzzi, 2007).

Ellis mulai mempraktikkan Konseling Rasional Emotive Behavior pada tahun 1950an dan memplubikasikan pertama kali pada tahun 1962 (Seligman, 2006). Ellis menggunakan Konseling Rasional Emotif Perilaku untuk menangani kesulitan-kesulitan yang dialaminya di hari tuanya, yakni kemampuan yang disebabkan karena menderita diabetes, mata, dan menurunnya pendengaran, dan ketidakmampuannya yang lain. Pada usia 90 tahun, Ellis masih energik dan 
produktif. Dia masih terus bekerja selama 7 hari dalam satu minggu dan tentu saja dia masih menjadi seorang penulis yang banyak menghasilkan tulisan mengenai konseling dan psikoterapi (Gladding, 2009).

Melalui Konseling Rasional Emotif Perilaku, Ellis mengakui bahwa kognisi, emosi dan perilaku saling berinteraksi dan saling mempengaruhi (Bond \& Dryden, 1996). Jika Rasional Emotive hanya menekankan pada aspek kognitif dan emosi, maka melalui Konseling Rasional Emotif Perilaku Ellis mulai memberikan perhatian pada aspek behavior dalam proses perlakuannya. Meskipun demikian Konseling Rasional Emotif Perilaku tetap menekankan pada peran penting kognisi dalam mempengaruhi fungsi manusia. Dalam hal ini, Konseling Rasional Emotif Perilaku menggunakan asumsi bahwa mengubah kognisi dalam pernyataan diri lebih menjadi lebih rasional merupakan cara paling efektif untuk meningkatkan fungsi tiga aspek diri tersebut. Karena asumsinya itu maka Konseling Rasional Emotif Perilaku dapat diklasifikasikan kedalam pendekatan integratif. Konseling Rasional Emotif Perilaku merupakan suatu pendekatan yang menekankan adanya perubahan dalam pola keyakinan yang dianut tiap manusia dengan memasukkan aspek perilaku dalam sistem teori dalam pendekatannya. Jika dalam konseling Rasional Emosi yang lebih ditekankan adalah aspek kognitif dan emosi seseorang, namun dalam Konseling Rasional Emotif Perilaku ini, aspek perilaku juga ditekankan berdampingan dengan aspek kognitif dan emosi.

\section{Hakikat Manusia}

Konseling Rasional Emotif Perilaku didasarkan pada asumsi bahwa Manusia pada dasarnya adalah unik yang memiliki kecenderungan untuk berpikir rasional dan irasional. Ketika berpikir dan bertingkah laku rasional manusia akan efektif, bahagia, dan kompeten. Ketika berpikir dan bertingkah laku irasional individu itu menjadi tidak efektif. Reaksi emosional seseorang sebagian besar disebabkan oleh evaluasi, interpretasi, dan filosofi yang disadari maupun tidak disadari. Keberfungsian individu secara psikologis ditentukan oleh pikiran, perasaan dan tingkah laku. Tiga aspek ini saling berkaitan karena satu aspek mempengaruhi aspek lainnya (Habsy, 2014),

Keyakinan irasional itu yang menyebabkan gangguan emosional, yang berbaur dengan hal-hal yang berasal dari luar manusia akan tetapi manusia tetap bertahan pada sikap yang cenderung mengalahkan diri dengan suatu proses indokrinasi diri sendiri. Untuk mengatasi indokrinasi yang membawa hasil berpikir irasional itu, maka para konselor dari Konseling Rasional Emotive Behavior menggunakan teknik-teknik yang bersifat aktif dan direktif seperti mengajar, memberi saran, membujuk, dan pemberian tugas pekerjaan rumah, dan mereka menantang konseli-konselinya untuk mengganti keyakinan yang irasional dengan rasional (Gross \& Capuzzi, 2007). 
Ellis (2008: 16) menyebut bahwa sebagian landasan teori Konseling Rasional Emotif Perilaku dipetik dari pandangan filosofi, meskipun sebagian besar lainnya berasal dari konsep teori psikologi. Pandangan Ellis terhadap hakikat manusia adalah:

1) Arah Tujuan. Tujuan tetap hidup dan tujuan kesenangan terhindar dari rasa sakit yang merupakan dua arah tujuan yang dimaksudkan Ellis.

2) Untuk membangkitkan tujuan, maka emosi harus diperankan secara efektif dan diaktivasi ke arah yang rasional.

3) Manusia lahir dengan memiliki dua kekuatan yang sama besar yakni: (a) cenderung rasional, memelihara diri, dan aktualisasi diri, (b) cenderung irrasional, merusak diri atau menghancurkan diri. Manusia memiliki dua kecenderungan yaitu baik dan buruk, rasional dan irrasional.

4) Manusia memiliki kecenderungan untuk mendapatkan kenikmatan (hidonik) baik itu jangka pendek maupun jangka panjang.

5) Manusia memiliki kecenderungan berpikir rasional dan irrasional yang samasama besar.

6) Kecenderungan menilai diri. Manusia memiliki kecenderungan kuat menilai diri dan perilakunya sebagai baik atau buruk.

7) Manusia pada dasarnya mudah menerima prasangka, menerima penilaian orang lain atas dirinya dan semacamnya. Manusia memiliki kecenderungan mudah terpengaruh.

Berdasarkan kajian di atas, dapat disebut bahwa pandangan Konseling Rasional Emotive Behavior menekankan pentingnya "kerelaan menerima diri sendiri". Individu harus menerima diri apa adanya, menerima sebagaimana apa yang dicapai dan dihasilkannya. Melalui kesadaran tersebut, maka tidak seorang pun yang akan disalahkan, dilecehkan, apalagi dihukum atas keyakinan atau tindakan diri sendiri yang keliru. Ellis (2008) memiliki keyakinan bahwa manusia secara natural dapat menjadi orang yang mampu menolong dan mencintai sepanjang mereka tidak berpikir irasional. Menurut Ellis, manusia harus memiliki pandangan yang realistis tentang kekuatan dan kelemahannya, manusia akan lebih berharga jika mereka dapat menerima, menilai, dan meyakini diri mereka, bahkan ketika mereka kecewa dengan peristiwa yang tidak menyenangkan yang terjadi dalam kehidupannya. 


\section{DISKUSI}

\section{Perkembangan Perilaku}

\section{Struktur Kepribadian}

Pandangan pendekatan rasional emotif tentang kepribadian dapat dikaji dari konsep-konsep kunci teori Albert Ellis Kerangka pilar ini yang kemudian dikenal dengan konsep atau teori ABC. Model ini menyediakan alat yang berguna untuk memahami perasaan, pikiran, peristiwa, dan perilaku konseli. Interaksi dari berbagai komponen seperti pada Gambar 1 .

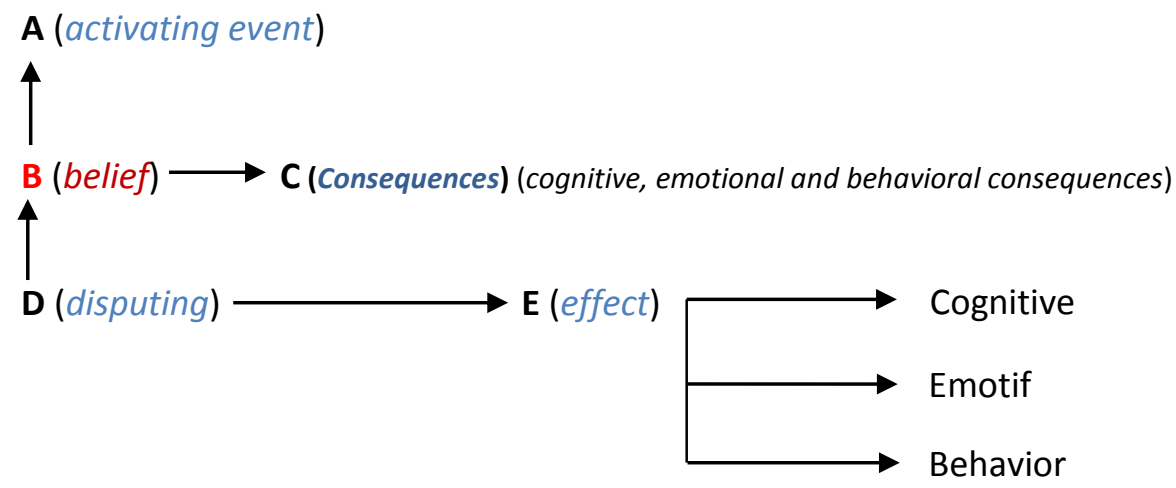

Activiting event (A) merupakan peristiwa pembangkit, pengakit yang berisi keberadaan suatu fakta, kejadian atau perilaku atau sikap orang-orang lain

Belief (B) berisi keyakinan (biliefs) atau verbalisasi diri atau "bisik dir" seseorang atas "Activiting event". Belief (B) keyakinan, pandangan, nilai, atau verbalisasi diri individu terhadap suatu peristiwa. Keyakinan seseorang ada dua macam, yaitu: (1) keyakinan yang rasional (rational belief atau rB) merupakan cara berpikir atau sistem keyakinan yang tepat, masuk akal, bijaksana, dan karena itu menjadi produktif, dan (2) keyakinan yang tidak rasional (irrasional belief atau iB) merupakan keyakinan atau sistem berpikir seseorang yang salah, tidak masuk akal, emosional, dan karena itu tidak produktif.

Consequence $(\mathrm{C})$ merupakan konsekuensi emosional sebagai akibat atau reaksi individu dalam bentuk perasaan senang atau hambatan emosi dalam hubungannya dengan antecendent event (A). Konsekuensi emosional ini bukan akibat langsung dari $A$ tetapi disebabkan oleh beberapa variable antara dalam bentuk keyakinan (B) baik yang $r B$ maupun yang iB.

Disputing (D), tindakan terapeutik untuk menjadikan irrasional ke rasional. Ellis memberi arahan pembenaran pikiran "D" (Disputing), dan setelah terjadinya 
disputing berlangsung muncul kehidupan efektif. Terdapat tiga bagian dalam tahap disputing, yaitu: 1) Detecting irrational beliefs. Konselor menemukan keyakinan konseli yang rasional dan membantu konseli untuk menemukan keyakinan irasionalnya melalui persepsinya sendiri; 2) Discriminating irrational beliefs. Biasanya keyakinan irasional diungkapkan dengan kata-kata: harus, pokoknya atau tuntutan-tuntutan lain yang tidak realistik. Membantu konseli untuk mengetahui mana keyakinan yang rasional dan yang tidak rasional; dan 3) Debating irrational beliefs. Beberapa strategi yang dapat digunakan: a) The lecture (mini-lecture), memberikan penjelasan; b) Socratic debate, mengajak konseli untuk beradu argument; c) Humor, creativity seperti: cerita, metaphors, dan lain-lain; d) Self-disclosure: keterbukaan konselor tentang dirinya (kisah konselor, dII)

Effect (E). Hasil akhir dari A-B-C-D berupa Effect (E) dari behavior, kognitif, dan emotif, bilamana A-B-C-D berlangsung dalam proses berpikir yang rasional dan logis, maka hasil akhirnya berupa perilaku positif, sebaliknya jika proses berpikir irasional dan ilogik maka hasil akhirnya berupa tingkah laku negatif.

\section{Pribadi Sehat dan Bermasalah}

Pribadi sehat, yaitu bilamana individu mampu menggunakan kemampuan berpikir rasional untuk memecahkan dan menghadapi masalah-masalah hidupnya secara bijak. Selain itu individu mampu memanfaatkan segala kelebihan dan keterbatasan dirinya serta mampu mengaktualisasikan diri, lebih percaya diri, dan tidak bergantung kepada orang lain serta dapat menyesuaikan diri di tengah-tengah lingkungannya (Corey, 1982).

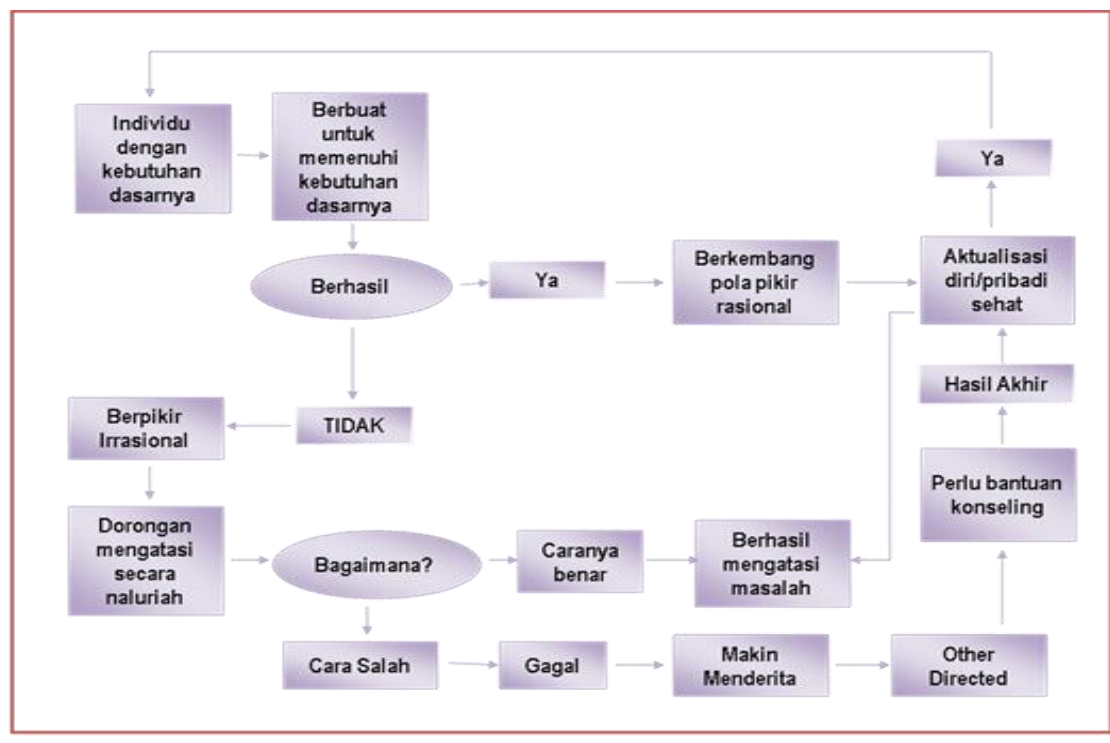

Gambar 2. Peralihan Pribadi Bermasalah Menjadi Pribadi Sehat 
Pribadi bermasalah dalam perspektif pendekatan konseling rasional emotif perilaku adalah tingkah laku yang didasarkan pada cara berpikir yang irrasional. Ciri-ciri berpikir irasional: (1) tidak dapat dibuktikan; (2) menimbulkan perasaan tidak enak (kecemasan, kekhawatiran, prasangka) yang sebenarnya tidak perlu; (3) menghalangi individu untuk berkembang dalam kehidupan sehari-hari yang efektif. Secara visual diagram proses pribadi bermasalah menjadi pribadi sehat dapat divisualkan seperti pada Gambar 2.

\section{Hakikat Konseling}

Konseling rasional emotif perilaku dilakukan dengan menggunakan prosedur yang bervariasi dan sistematis yang secara khusus dimaksudkan untuk mengubah tingkah laku dalam batas-batas tujuan yang disusun secara bersamasama oleh konselor dan konseli. Karakteristik Proses Konseling Rasional Emotif Perilaku:

1) Aktif-direktif, artinya bahwa dalam hubungan konseling konselor lebih aktif membantu mengarahkan konseli dalam menghadapi dan memecahkan masalahnya.

2) Kognitif-eksperiensial, artinya bahwa hubungan yang dibentuk berfokus pada aspek kognitif dari konseli dan berintikan pemecahan masalah yang rasional.

3) Emotif-ekspreriensial, artinya bahwa hubungan konseling yang dikembangkan juga memfokuskan pada aspek emosi konseli dengan mempelajari sumber-sumber gangguan emosional, sekaligus membongkar akar-akar keyakinan yang keliru yang mendasari gangguan tersebut.

4) Behavioristik, artinya bahwa hubungan konseling yang dikembangkan hendaknya menyentuh dan mendorong terjadinya perubahan tingkah laku konseli.

\section{Kondisi Pengubahan}

\section{Tujuan}

Tujuan umum Konseling rasional emotif perilaku yaitu membantu individu mengidentifikasi sistem keyakinannya yang tidak rasional dan kemudian memodifikasinya agar menjadi lebih rasional. Secara Konseling rasional emotif perilaku memusatkan perhatian pada upaya membantu individu untuk belajar memperoleh keterampilan yang memudahkannya untuk membentuk pikiranpikiran yang lebih rasional, mengarahkan pada penerimaan diri dan kebahagiaan yang lebih besar dan mendorong kesanggupan untuk dapat lebih menikmati hidupnya (Prochaska \& Norcross, 2007). Menghilangkan gangguan-gangguan emosional yang merusak diri sendiri seperti rasa takut, rasa bersalah, rasa berdosa, rasa cemas, merasa was-was, rasa marah. 


\section{Tugas Konselor}

Pertama, konselor perlu memperhatikan dan menunjukkan pada konseli bahwa masalah atau kesulitan yang dihadapinya sangat berhubungan dengan keyakinan yang irasional dan menunjukkan bagaimana konseli harus mengembangkan nilai dan sikapnya dengan mencoba memberikan wawasan dengan menunjukkan istilah seperti: should, ought, dan must. Dalam hal ini konseli harus belajar memisahkan keyakinan yang rasional dengan keyakinan irasional.

Kedua, setelah konseli menyadari keadaan diri yang sebenarnya, bahwa gangguan emosi dalam dirinya disebabkan oleh sikap, persepsi dan penilaian terhadap dirinya yang tidak rasional maka konselor menunjukan kepada konseli bahwa berpikir irasional adalah sumber dan gangguan terhadap kepribadiannya, namun hal tersebut dapat diubah dengan membuat dan mengubah keyakinannya dengan pandangan-pandangan baru yang logik dan rasional

Ketiga, Konselor mencoba mengarahkan konseli untuk untuk berpikir dan membebaskan ide-ide yang irasional. Pada langkah ini konselor harus menolong konseli untuk memahami hubungan antara ide-ide yang merusak dirinya sendiri dan pandangan yang tidak realistik yang membawa ke arah proses menyalahkan diri sendiri.

Keempat, dalam proses konseling, konselor "menantang" konseli untuk mengembangkan filosofi hidupnya yang rasional dan mencoba untuk menolak keyakinan-keyakinan irasional (Seligman, 2006).

\section{Tugas Konseli}

Proses konseling dapat dipandang sebagai proses redukatif yang mana konseli belajar cara mengaplikasikan pemikiran logis untuk memecahkannya. Pengalaman yang harus dimiliki klien/konseli adalah pengalaman masa kini dan di sini (here and now experiences), dan kemampuan konseli untuk mengubah pola berpikir dan emosinya yang salah.

Pengalaman utama konseli adalah mencapai pemahaman emosional atas sumber-sumber gangguan yang dialaminya. Pada taraf pertama, konseli menjadi sadar bahwa ada anteseden tertentu yang menyebabkan timbulnya irrasional belief. Taraf kedua, konseli mengakui dirinyalah yang sekarang mempertahankan pikiran-pikiran dan perasaan-perasaan yang irrasional. Taraf ketiga, konseli berusaha untuk menghadapi secara rasional-emotif, memikirkannya, dan berusaha menghapus irrational belief dan mengggantinya dengan rational belief.

Konseli yang telah memiliki keyakinan rasional terjadi peningkatan dalam hal: (1) minat kepada diri sendiri, (2) minat sosial, (3) pengarahan diri, (4) toleransi 
terhadap pihak lain, (5) fleksibel, (6) menerima ketidakpastian, (7) komitmen terhadap sesuatu di luar dirinya, (8) penerimaan diri, (9) berani mengambil risiko, dan (10) menerima kenyataan.

\section{Situasi Hubungan}

Menutur Ellis, kehangatan pribadi, afeksi, dan hubungan pribadi antar konselor dan konseli yang intens memiliki arti yang sekunder. Bagaimana pun hubungan yang baik antara konseli dan konselor merupakan sesuatu yang sangat diharapkan. Konselor memainkan peran sebagai model yang tidak terganggu secara emosional dan yang hidup secara rasional. Konselor juga menjadi model orang yang berani bagi konseli dalam arti dia secara langsung mengungkapkan sistem-sistem keyakinan konseli yang irasional tanpa takut kehilangan rasa suka dan persetujuan dari konseli. Lebih dari itu, konseling REB menekankan toleransi penuh dan penghormatan tanpa syarat dari terapis terhadap kepribadian konseli dalam arti konselor menghindari sikap menyalahkan konseli. Sifat-sifat hubungan yang dianggap penting adalah:

1) Pertautan hubungan baik (good rapport)

2) Gaya hubungan dalam REB harus aktif, direktif, dan objektif

3) Hubungan REB menekankan pentingnya dull tolerance, dan uncanditioning positive regard.

4) Secara terus menerus konselor perlu menerima diri konseli sebagai seorang worthwhile human being (manusia hidup berharkat dan bernilai), karena the client exist bukan karena the client accomplishments.

\section{Teknik-Teknik Konseling}

Konseling REB dalam praktik terapinya memberi arahan adanya langkah konstruktif yang selalu dipergunakan oleh konselor untuk melakukan perubahan pemikiran irrasional menjadi rasional (Nelson-Jones, 2001; Parrot III, 2003; Prochaska \& Norcross, 2007; Ellis, 2008). Dalam praktiknya, Ellis merekomendasikan sejumlah teknik yaitu:

Mengajar dan Memberi Informasi. Teknik ini dipandang sebagai tindakan yang mana konselor mengawal siswa untuk dapat membedakan antara pemikiran rasional dan pemikiran irrasional dan memahami asal muasal terjadinya masalah. Melalui teknik ini, konselor (dengan berbagai metode) mengajar siswa (1) membebaskan diri dari pandangan yang irasional sehingga mereka dapat menentukan pilihan tingkah laku yang efektif dan terhindar dari adanya ancaman, (2) menemukan cara-cara atau tindakan-tindakan yang lebih tepat untuk merespon keadaan (realitas) sehingga siswa tidak terganggu oleh adanya realita yang dihadapi. Isi informasi yang diajarkan oleh konselor adalah dinamika konsep 
A-B-C-D-E yang dikaitkan dengan realitas yang dihadapi siswa, sehingga pemecahan masalah dan pemilihan tingkah laku efektif yang didasarkan pada pengalaman-pengalaman konselor dan anggota dalam kelas dapat terjadi. Proses ini secara ekplisit dikenal sebagai proses "E" (experiencing).

Mendiskusikan Masalah. Diskusi dalam konseling kelompok REBT diarahkan dengan memanfaatkan pengalaman kelompok untuk mendukung informasi konselor. Para anggota kelompok yang rasional cenderung akan memahami dan menjadikan informasi konselor sebagai bagian pengalaman dan dipandang sebagai sumber pemecahan masalah dan pemilihan tingkah laku yang efektif. Semua ini selanjutkan akan mereka kembangkan dengan mengungkap pengalaman-pengalaman anggota kelompok secara simultan yang dalam bahasan ini secara jelas disebut sebagai proses experiencing.

Mempropagandakan Berpikir IImiah. Ciri berpikir ilmiah adalah adanya obyek yang jelas sistematis dan metodis. Obyek yang jelas ditandai oleh adanya realitas yang dihadapi oleh siswa; sistematis dalam arti proses pemahaman dan obyek realistis dari pengalaman masing-masing anggota siswa terungkap secara berurutan berada pada posisi sinergis. Dalam seting ini, konselor juga mendorong siswa untuk menguji pandangannya dengan cara meninjau sebab-sebab realita emosi yang terjadi pada dirinya, akibat-akibat yang terjadi dan mungkin terjadi. Cara pandang yang didasarkan pada prinsip-prinsip ilmiah menjadi sangat penting dalam seting ini. Diantara beberapa prinsip ilmiah, ada beberapa yang dapat dikemukakan: mendasarkan pikiran dalam bentuk mengemukakan beberapa proposisi atau rumusan-rumusan logis, (2) menguji rumusan logis ke dalam suatu kerangka berpikir yang melibatkan pengalaman (diri sendiri atau orang lain) dan membuat prediksi-prediksi logis. Dalam prosesnya, seting ini dapat terjadi perubahan-perubahan sistem keyakinan magis siswa, (Ellis, 1973) yang secara sistematis timbul oleh karena keaktifan konselor, didaktif dan filosofis yang memancing tindakan nyata siswa di waktu-waktu luar sekolah.

Mengkonfrontasikan dan Menantang. Setelah proses berpikir ilmiah berjalan dengan efektif, selanjutnya siswa diharapkan dapat menantang dan menghadapi pemikiran irrasional. Itu dapat lebih efektif jika siswa dapat menyadari sepenuhnya bahwa pemikiran irrasional yang selama ini ia pertahankan justru akan merusak diri dan masa depannya, serta mereka berani mengemukakan beberapa jalan pikiran yang benar, terhindar dari cara pandang irrasional serta dapat mengemukakan kemungkinan jalan berpikir yang benar.

Modeling. Pemodelan atau modeling adalah metode untuk menghasilkan perilaku baru (Gazda, 1989, p. 93), atau prosedur dengan mana orang dapat belajar perilaku yang diharapkan melalui pengamatan terhadap perilaku orang lain (Cormier dan Cormier,1985). Modeling efektif untuk mengarahkan partisipan 
untuk menata dirinya sendiri dengan cara melihat karakter atau kepribadian seseorang yang kemudian dapat dimengerti oleh partisipan dan dipedomani sebagai sumber arah diri (Ellis, 2008).

\section{Teknik-Teknik Emotif}

Assertive Adaptive. Teknik yang digunakan untuk melatih, mendorong, dan membiasakan konseli untuk secara terus-menerus menyesuaikan dirinya dengan tingkah laku yang diinginkan. Latihan-latihan yang diberikan lebih bersifat pendisiplinan diri konseli.

Bermain Peran (role playing). Teknik untuk mengekspresikan berbagai jenis perasaan yang menekan (perasaan-perasaan negatif) melalui suatu suasana yang dikondisikan sedemikian rupa sehingga konseli dapat secara bebas mengungkapkan dirinya sendiri melalui peran tertentu.

Imitasi. Teknik untuk menirukan secara terus menerus suatu model tingkah laku tertentu dengan maksud menghadapi dan menghilangkan tingkah lakunya sendiri yang negatif.

\section{Teknik-teknik Behavioristik}

Reinforcement. Teknik ini dimaksudkan untuk membongkar sistem nilai dan keyakinan yang irrasional pada konseli dan menggantinya dengan sistem nilai yang positif. Dengan memberikan reward ataupun punishment, maka konseli akan menginternalisasikan sistem nilai yang diharapkan kepadanya.

Social Modeling. Teknik untuk membentuk tingkah laku-tingkah laku baru pada konseli. Teknik ini dilakukan agar konseli dapat hidup dalam suatu model sosial yang diharapkan dengan cara imitasi (meniru), mengobservasi, dan menyesuaikan dirinya dan menginternalisasikan norma-norma dalam sistem model sosial dengan masalah tertentu yang telah disiapkan oleh konselor.

\section{Teknik-teknik Kognitif}

Home Work Assigments. Teknik yang dilaksanakan dalam bentuk tugastugas rumah untuk melatih, membiasakan diri, dan menginternalisasikan sistem nilai tertentu yang menuntut pola tingkah laku yang diharapkan. Dengan tugas rumah yang diberikan, konseli diharapkan dapat mengurangi atau menghilangkan ide-ide dan perasaan-perasaan yang tidak rasional dan tidak logis, mempelajari bahan-bahan tertentu yang ditugaskan untuk mengubah aspek-aspek kognisinya yang keliru, mengadakan latihan-latihan tertentu berdasarkan tugas yang diberikan. Pelaksanaan home work assigment yang diberikan konselor dilaporkan oleh konseli dalam suatu pertemuan tatap muka dengan konselor. Teknik ini dimaksudkan untuk membina dan mengembangkan sikap-sikap tanggung jawab, 
kepercayaan pada diri sendiri serta kemampuan untuk pengarahan diri, pengelolaan diri konseli dan mengurangi ketergantungannya kepada konselor.

Latihan Assertive. Teknik untuk melatih keberanian konseli dalam mengekspresikan tingkah laku-tingkah laku tertentu yang diharapkan melalui bermain peran, latihan, atau meniru model-model sosial. Maksud utama teknik latihan asertif adalah: (a) mendorong kemampuan konseli mengekspresikan berbagai hal yang berhubungan dengan emosinya; (b) membangkitkan kemampuan konseli dalam mengungkapkan hak asasinya sendiri tanpa menolak atau memusuhi hak asasi orang lain; (c) mendorong konseli untuk meningkatkan kepercayaan dan kemampuan diri; dan (d) meningkatkan kemampuan untuk memilih tingkah laku-tingkah laku asertif yang cocok untuk diri sendiri.

Disputing Irrational Beliefs. Jika saya tidak mendapatkan apa yang saya inginkan, hal itu bukanlah merupakan akhir dunia/kehidupan.

Doing Cognitive Homework. Menerapkan teori ABC dalam menghadapi masalah kehidupan sehari-hari. Menempatkan diri dalam situasi yang berisiko untuk menantang keyakinan membatasi diri (self -limiting). Menganti pernyataandiri (self-statement) negatif dengan pesan yang positif.

\section{Tahap-Tahap Konseling}

Menurut Corey (2012), pelaksanaan Konseling Rasional emotif perilaku, terdiri dari tiga tahapan, yaitu initial stage, working stage dan final stage. Siklus terapi didasarkan atas formulasi Dobson (2013) dan Ellis (2008), peneliti mengintegrasikan siklus tersebut dalam tahapan Konseling emotif behavior, yaitu:

\section{Initial Stage}

Sesi pertama, bertujuan melakukan assesment sebagai baseline dari kondisi pra-konseling. Assesment dilakukan, terhadap belive yang ditengarai mempengaruhi Activating event dan consequence individu (konseli) tersebut, selanjutnya, dilakukan interpretasi dan pengujian belief atau bisik diri, konseli yang bersifat rasional ataupun irasional.

Menurut Corey (2012), Belief (B) adalah keyakinan, pandangan, nilai, atau verbalisasi diri individu terhadap suatu peristiwa yang mengarah pada respon activating event dan consequence. Menurut Jose A. Corraliza (2008) belief adalah memiliki peran yang lebih besar untuk mengubah lingkungan dibanding kebutuhan dan pengetahuan.

Pada sesi ini konselor harus dapat mengidentifikasi masalah secara spesifik, konseli diperkenankan untuk menceritakan terlebih dahulu hal-hal yang 
membuat mereka ingin mengikuti konseling dan masalah yang dialami, diskusi mengenai harapan konseli membuat mereka lebih santai. Setelah diketahui semua keterkaitan dan kedalaman dari masing-masing aspek, serta bentuk permasalahanya, konselor merumuskan tujuan konseling yang akan dilaksanakan.

\section{Working Stage}

Setelah perumusan tujuan, dilakukan perencanaan dan perumusan treatment bersama dengan konseli, serta dilakukan kontrak atau komitmen secara prosedural dan terjadwal. Pada tahap ini, konseli diajak untuk menjalankan peran aktifnya dalam mengatasi permasalahan, konseli dibantu untuk yakin bahwa pemikiran dan perasaan negatif tersebut dapat ditantang dan diubah. Konseli mengeksplorasi ide-ide untuk menentukan tujuan-tujuan rasional. Konselor juga mendebat pikiran irasional konseli (dispute) dengan menggunakan teknik-teknik konseling untuk menantang validitas ide tentang diri, orang lain dan lingkungan sekitar.

\section{Final stage}

Menurut Corey (2012, p. 359), pada tahap ini pilihan kegiatan yang dilaksanakan oleh konselor adalah:

1) Memberi dan menerima balikan

2) Memberi kesempatan untuk mempraktikan perilaku baru

3) Belajar lebih lanjut dari pengembangan perencanaan yang spesifik untuk mengaplikasikan perubahan pada situasi diluar terapi (konseling)

4) Mempersiapkan untuk menghadapi adanya kemungkinan memburuk

5) Mendampingi dalam meninjau pengalaman dan pemaknaan bagi dirinya.

Tahap-tahap Konseling Rasional emotif perilaku seperti divisualkan pada Gambar 3. 


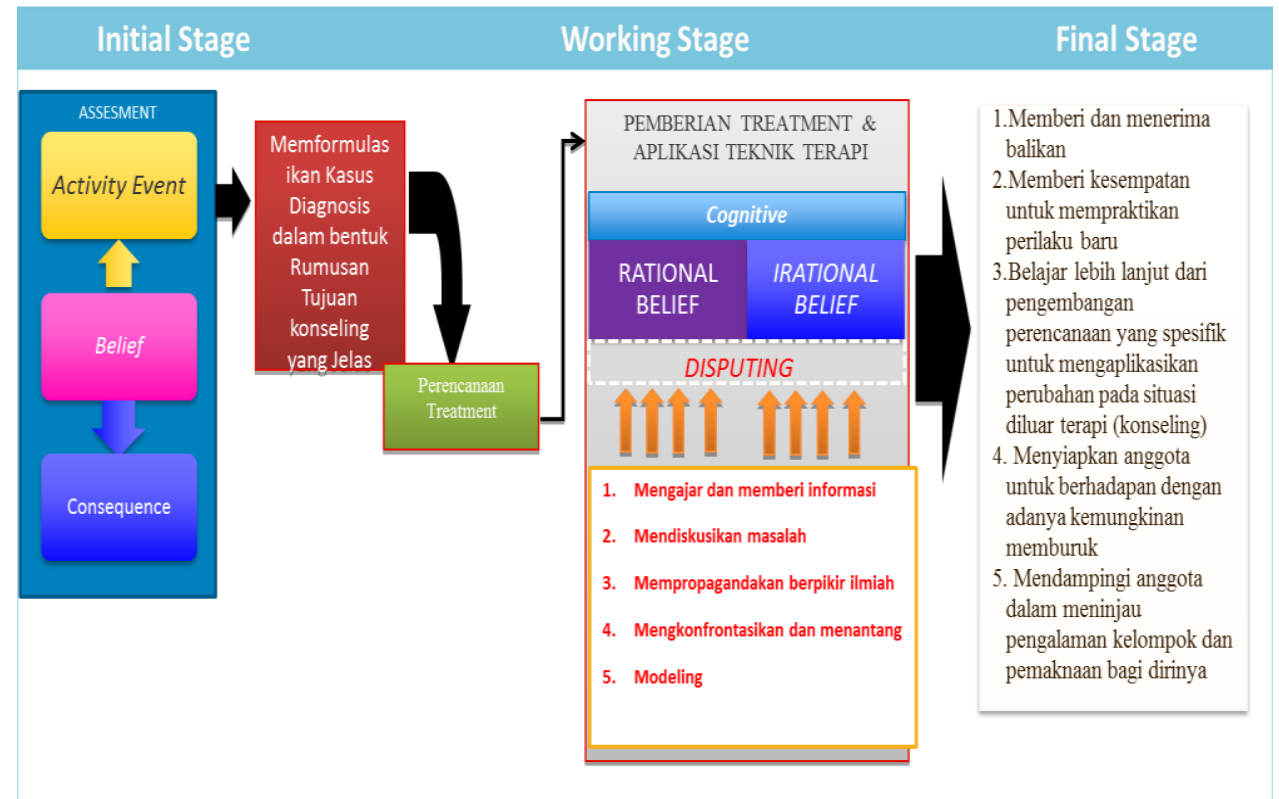

Gambar 3. Tahap-tahap Konseling Rasional Emotif Perilaku

\section{Kerangka Berpikir}

Konseling Rasional Emotif Perilaku didasarkan pada asumsi bahwa manusia dilahirkan dengan potensi pemikiran yang rasional maupun "lurus", serta pemikiran irrasional atau "melenceng". Manusia memiliki predisposisi untuk selfpreservation, berbahagia, berpikir, verbalisasi, mencintai, komunikasi dengan orang lain, dan bertumbuh serta mengaktualisasi diri. Manusia juga memiliki kecenderungan untuk merusak diri, menghindari pemikiran, penangguhan, pengulangan kesalahan yang terus dilakukan, takhayul, intolerance, perfeksionisme, dan menyalahkan diri, dan penghindaran dari aktualisasi potensi diri.

Ellis berasumsi bahwa manusia adalah mahluk yang berbicara pada diri sendiri, mengevaluasi diri, dan memberikan dukungan pada diri sendiri. Manusia mengembangkan masalah emosional dan tingkah lakunya apabila membuat kesalahan pilihan sederhana (hasrat untuk cinta, persetujuan, sukses). Ellis juga menjelaskan bahwa individu memiliki kecenderungan sejak lahir untuk tumbuh dan beraktualisasi, namun sering menyabotase kemajuannya sendiri karena pola pengalahan diri yang dipelajari. Kerangka berpikir Konseling Rasional emotif perilaku seperti divisualkan pada Gambar 4. 


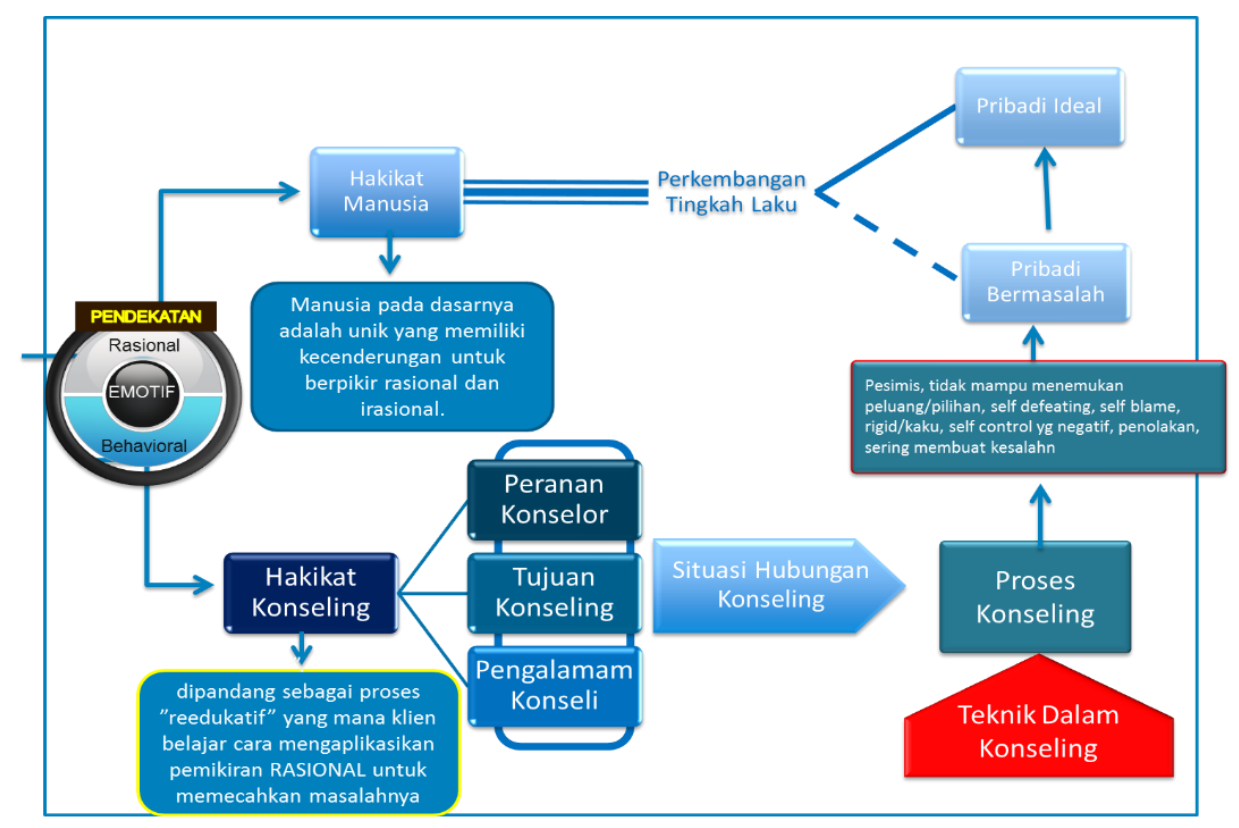

Gambar 4. Kerangka Berpikir Konseling Rasional Emotif Perilaku

\section{SIMPULAN}

Konseling Rasional Emotif Perilaku dipandang sebagai Model terapi perilaku yang berorentasi kognitif. Pendekatan ini telah mengalami evolusi sedemikian rupa, yang pada akhirnya menjelma menjadi pendekatan yang komprehensif dan eklektik yang menekankan unsur-unsur berpikir, menimbang, memutuskan dan melakukan. Akan tetapi pendekatan ini masih tetap mempertahankan arah pemikiran Ellis sendiri yang bersifat didaktis dan direktif, dan masih tetap mempertahankan dimensi berpikir dibandingkan dimensi perasaan.

Konseling Rasional Emotif Perilaku sangat fleksibel, sehingga digunakan dalam berbagai macam cara dengan berbagai macam populasi konseli. REBT juga sangat baik untuk diadministrasikan sebagai pendekatan dalam konseling kelompok dan sangat efektif untuk menangani berbagai konflik dalam keluarga dan perkawinan.

Secara khusus, REBT dapat diterapkan secara efektif untuk menangani kesulitan-kesulitan kognitif, emosi, dan perilaku yang berkaitan dengan distress psikologis dan psikopatologi, serta untuk berbagai gangguan emosi dan perilaku seperti agresi, kecemasan, depresi, hiperaktif, kecanduan alkohol, dan kegemukan khususnya pada kelompok populasi anak-anak. 


\section{REFERENSI}

Bond, F. W., \& Dryden, W. (1996). Why two, central REBT hypotheses appear untestable. Journal of Rational-Emotive \& Cognitive-Behavior Therapy, 14(1), 29-40.

Corey, G. (1982). Ethical considerations in using group techniques. Journal for Specialists in Group Work, 7(3), 140-148.

Corey, G. (2012). Case approach to counseling and psychotherapy. Toronto: Nelson Education.

Corey, G. (2015). Theory and practice of counseling and psychotherapy. Toronto: Nelson Education.

Dobson, K. S. (2013). The science of CBT: Toward a metacognitive model of change?. Behavior therapy, 44(2), 224-227.

Dryden, W. (Ed.). (2003). Rational emotive behaviour therapy: theoretical developments. Psychology Press.

Ellis, A. (2008). Rational emotive behavior therapy: A therapist's guide. California: Impact Publishers.

Ellis, A., Grieger, R. M. (Eds.). (1986). Handbook of rational-emotive therapy. New York: Springer.

Gladding, S. T. (2009). Konseling: Profesi yang menyeluruh (Edisi enam). Jakarta: Indeks. (Counseling: A comprehensive profession. Original work published 1988).

Gross, D. R., \& Capuzzi, D. (2007). Helping relationships: From core dimensions to brief approaches. Counseling and psychotherapy: Theories and interventions, 3-25.

Habsy, B. A. (2014). Teori dan pendekatan konseling modern dan post modern. UNDAR Press.

Habsy, B. A. (2017). Model konseling kelompok cognitive behavior untuk meningkatkan self esteem siswa SMK. Perspektif Ilmu Pendidikan, 31(1), 21-35. 
Nelson-Jones, R. (2001). Theory and practice of counseling and therapy. London: Sage Publications.

Parrot III, L. (2003). Counseling and psychotherapy. Pacific Grove, CA: Brooks/Cole.

Prochaska, J. O., \& Norcross, J. C. (2007). Systems of psychotherapy. Belmont, CA: Thomson Brooks/Cole.

Seligman, L. (2006). Theories of counseling and psychoterapy. Columbus, Ohio: Person Merril Prentice Hall. 